GLOBAL MEDICAL ETHICS

\title{
Human rights and the national interest: migrants, healthcare and social justice
}

Phillip Cole

J Med Ethics 2007;33:269-272. doi: 10.1136/ime.2005.014829

The UK government has recently taken steps to exclude certain groups of migrants from free treatment under the National Health Service, most controversially from treatment for HIV. Whether this discrimination can have any coherent ethical basis is questioned in this paper. The exclusion of migrants of any status from any welfare system cannot be ethically justified because the distinction between citizens and migrants cannot be an ethical one.

Correspondence to:

Dr P Cole, Middlesex

University, Trent Park,

Bramley Road, London N14

$4 Y Z, U K$;

p.cole@mdx.ac.uk

Received 17 February 2006

Revised 7 July 2006

Accepted 18 July 2006
$\mathrm{T}$ he international human rights system depends on national governments for its enforcement; however, national governments predominantly regard their obligations under that system as owed to their own citizens, and this leaves a substantial number of people in a precarious position. We can describe this group as "migrants", although we must keep in mind that this category includes a broad range of people in diverse situations. ${ }^{\mathrm{i}}$ However, they are all nonnationals of the states within which they reside, and so, from the perspective of the national government, have secondary status. By contrast, as the United Nations Special Rapporteur of the Commission on Human Rights Gabriela Rodriguez Pizarro made clear in her report on the human rights of migrants, submitted to the General Assembly in August 2002, the United Nations interprets its charter of human rights as applying to all people, regardless of their status, and therefore takes the view that a national government has an equal obligation to respect, enforce and deliver human rights to all people within their territory.

The purpose of the provisions of the Declaration and the international instruments is to protect, without distinction, every person without exception within the jurisdiction of a state. ${ }^{\text {ii }}$

In this paper, I focus on one particular aspect of this issue, that of access to healthcare, and I narrow this further by looking at the issue of migrants within the UK, and at the legislation in place to restrict the free access of certain groups of migrants to the medical treatment provided by the National Health Service (NHS). ${ }^{2}$ Crucially, I narrow the issue even further by asking whether this restriction can have an ethical basis. This is a central question because, as we shall see, the British government presented this discrimination in specifically ethical terms, and so there must be a moral argument here somewhere. Also, the question has wide implications for the very idea of social justice, especially for those committed to a moral vision of state provision of welfare, some form of the welfare state, as the best way to deliver it. If we cannot find a way of making an ethically principled distinction between citizens and migrants that can act as a moral basis for discrimination when it comes to access to free medical treatment and other forms of welfare, and if it turns out that it is impossible to supply such a welfare system without such discrimination, then we may find that what many regard as a highly ethical project rests on deeply immoral foundations.

\section{THE UK LEGISLATION AND HIV}

The UK does not exclude migrants from all access to welfare provision, and remains fairly generous on this question, including access to free medical treatment. David Jacobson ${ }^{3}$ points out that western European states have generally legislated to include migrants and their families within their social and welfare systems. "In the area of social services-such as education, health insurance, welfare, and unemployment benefits-citizenship status is of minor importance. Physical presence and legal alien status are the determining criteria."

Abbreviation: NHS, National Health Service

IIn her report to the United Nations General Assembly, the Special Rapporteur of the Commission on Human Rights Gabriela Rodriguez Pizarro proposed that the following should be considered as migrants: persons who are outside the territory of the State of which they are nationals or citizens, are not subject to its legal protection and are in the territory of another State; persons who do not enjoy the general legal recognition of rights which is inherent in the granting by the host State of the status of refugee, naturalized person or of similar status; persons who do not enjoy general legal protection of their fundamental rights by virtue of diplomatic agreements, visas or other agreements. See "Human rights of migrants", $p$ 12. For the role of the Special Rapporteur, see www.ohchr.org/ english/issues/migration/rapporteur/

iSee "Human rights of migrants", , p 7. The United Nations Commission on Human Rights resolution 2000/48 affirms that "every State party to the International Covenant on Economic, Social and Cultural Rights must undertake to guarantee that the rights enunciated in that Covenant will be exercised without discrimination of any kind, including on the basis of national origin". See www.unhchr.ch/ huridocda/huridoca.nsf/(Symbol)/E.CN.4.RES.2000.48. En? Opendocument 
However, the European mood is changeable and in many countries has become increasingly hostile to migration, and in the UK this hostility took the form of legislation aimed at the problem known as "health tourism", where people allegedly visit expressly for free treatment. In arguing for these restrictions in 2003, the then Health Secretary John Reid said: "If there are bona fide tourists dropping ill on the streets, of course we will do what we have to, but we are not mugs. There is a difference between being civilised and being taken for a ride." Failed asylum seekers, for example, were "effectively stealing treatment from the people of this country". He concluded: "I am not talking about emergency treatment, matters of life and death. I am talking about routine treatment that causes the people of this country, who are legally and morally entitled to it, to have to wait longer." ${ }^{\prime i i i}$ Notice that it is the moral aspect of the argument that has to do all the work here, because, before the changes in the regulations, failed asylum seekers were legally entitled to the treatment in question.

However, this kind of restriction is not new. The regulations were clarified in 1989 when NHS hospital services were obliged to establish whether a patient was an overseas visitor, and if so to charge for any treatment. There were exceptions: where a person was exempt from charges, so were their spouse and children; people on legitimate business trips and their family were exempt; and, most crucially, anybody who had spent the previous 12 months in the UK was exempt. However, one of the amendments to the regulations in 2004 changed the last rule so that only people living in the UK legally for the past 12 months were exempt, and as a result illegal immigrants, failed asylum seekers, those who have overstayed their visa and others living in the country without proper authority, are no longer eligible and must now pay for treatment (Select Committee on Health ${ }^{4}$ paragraph 94). There are still exemptions in these cases: they will not be charged (1) if they have a serious communicable disease that is exempt on public health grounds, including tuberculosis and all sexually transmitted diseases apart from HIV, (2) if they seek treatment in an accident and emergency department and (3) if they require compulsory mental health treatment (Select Committee on Health ${ }^{4}$ paragraph 95). Other changes state that where treatment is judged to be immediately necessary to save life or prevent a condition from becoming life threatening, that treatment must be given before determining whether the patent is chargeable; but this must be determined subsequently and the patient advised as soon as possible, and all costs must be recovered (Select Committee on Health ${ }^{4}$ paragraph 96-97). With respect to primary care, the government is currently considering proposals to bring it in line with secondary care, such that the same categories of migrants must be charged for treatment. At present, general practitioners have the discretion to accept individuals for NHS treatment (Select Committee on Health ${ }^{4}$ paragraphs 99-100).

The House of Commons Select Committee on Health, in its third report published in March 2005, focused on the exclusion of failed asylum seekers with HIV. After hearing evidence from government ministers, medical experts and other groups, they reached heavily critical conclusions. The committee recommended that free treatment be given to all patients with HIV regardless of immigration status, and that HIV should be reclassified as a sexually transmitted infection, which would make treatment free automatically (Select Committee on Health $^{4}$ paragraph 177).

\section{THE LIBERAL PROBLEM}

Although the Select Committee questioned the coherence of the government's restrictions, ${ }^{\text {iv }}$ the question I raise here is whether this specific discrimination can have any ethical basis. This is an important issue because the British government presented it as an ethical discrimination and also because it raises wider questions of migrant access to state welfare systems, and poses the problem of whether any exclusion can be morally defended. One obvious place to begin this general argument is at the national border. Where national borders fall is morally arbitrary-they might be the result of war, geography or discovery; but from a liberal point of view national borders cannot bear much, if any, moral weight. What is of interest to moral theory is not the processes through which territorial boundaries become fixed in particular places, but how the distinction between insiders and outsiders is established, the boundaries of membership.

This is a more promising place to begin, because despite the fact that many membership practices are devoid of any ethical foundation, they need not be, and therefore an ethical distinction between citizens and migrants remains a possibility. And in actual fact, practices of membership are much broader and more complex than the drawing of a border around a territory: one does not gain membership when one enters a territory nor lose it when one leaves. And although the national border may be a convenient place to police membership, there are other places and ways in which this can be done. In a world where there is a fair degree of freedom of movement across national borders, internal policing of membership takes on a much greater importance than border controls. And anyway, membership is not established at the border-whether one is a citizen, a tourist, a migrant, an asylum seeker and so on may be made clear at the border, but these distinctions and who falls into which class are established elsewhere; and what they actually mean is determined by the internal practices of the particular state.

Having made these points, territorial borders and membership boundaries remain connected, as it is one's relationship with the territorial space within the border that plays some role in determining one's membership-whether one was born within it, or one's parents were, length of unbroken residence, prospects of employment there and so on. It is difficult to think of a practice of membership that has no relationship at all with territorial space, or even why such a practice would exist. This raises a worrying concern, because now the seemingly banal arbitrariness of the territorial border creates a disturbingly moral arbitrariness when it comes to membership. From the liberal point of view, many would argue, arbitrary factors to do with gender, "race", physical ability, height and so on should play no part in determining one's moral status or welfare; only free choice, not fate, should influence life chances. But which side of a national border one is born on, or one's parents were born on, is a matter of extreme moral arbitrariness, perhaps the clearest example of what moral arbitrariness means. And so from the liberal point of view, it should play little or no role in determining moral status, welfare or life chances. And yet, national membership plays a highly significant role in determining these things and, from the point of view of the nation state, is the key factor in deciding one's moral status. In the face of this clash, the liberal seems to have three options: the first is to drop national membership from their moral perspective; the second is to drop or compromise universalism from that perspective; and the third is to attempt a reconciliation between these two points of view.

iiiBBC news/health/'health tourism' rules unveiled, published 30 December 2003 at http/www.news.bbc.co.uk/go/pr/fr/-/hi/health/ $3355751 \mathrm{stm}$

iv Other organisations have pointed this out too. For the National Aids Trust's report to the Health Committee, see www.nat.org.uk 
The first option-dismissal of the moral significance of national membership-implies that, ethically, we should argue for free access to welfare systems regardless of status. This does not rule out all arguments for discrimination, only moral ones-but our concern here, of course, is with the possibility of moral argument. The second option-to drop or significantly revise the commitment to universalism-is a move towards some kind of accommodation with the body of moral theory known as particularism and a body of political theory known as communitarianism, and it has been attempted by a number of theorists, most notably Tamir ${ }^{5}$ and Miller. ${ }^{6}$ What we find here are versions of liberal communitarianism that fix on the nation as having moral value, and therefore allow it to play a moral role in justifying practices of discrimination between members and non-members. It is the particular community or the particular relationships that make it up, not humanity or personhood in general, which give rise to one's strongest moral duties, and therefore the principle of community outweighs the principle of humanity. I discuss liberal nationalism elsewhere, ${ }^{7}$ and reject it as an implausible approach. Here, I focus on liberal universalism and the attempt to reconcile it with emphasis on the national interests of citizens in maintaining welfare institutions.

\section{BEGGING THE LIBERAL QUESTION}

The second approach for the liberal is to attempt to reconcile the universal with the national, and one way of doing this is to argue that there is no contradiction here: the distinction between citizens and migrants can be made an ethical one through appeal to traditional liberal ideas. For example, we can argue that the priority of the rights of citizens over those of migrants has a clear moral basis. There is a morally grounded distinction between members and non-members so that their differential access to welfare resources can be explained purely in terms of people's different entitlements, depending on their differential rights. However, this approach is deeply flawed in that it cannot avoid begging the question. We are asking what makes the moral difference between members and nonmembers such that members have rights of access to welfare resources while non-members do not. If we answer that question by saying that what makes the difference is that members have the right of access while non-members do not, this just tells us what we already know. What we need to know is how the moral difference between members and non-members is generated in the first place. Neither can we say that a state has special obligations to its members that it does not have to non-members, because again this takes the distinction between members and non-members as morally given without telling us how to establish it in the first place.

Another, and perhaps the most obvious, argument illustrates this problem. We could say that in order to see who has rights to welfare, we should examine who has contributed to the economic prosperity that makes such a system possible through work and taxation. Surely those who have made this contribution have the right to receive the benefits of the system, whereas those who have made no such contribution have no such rights. We can clearly see that members of the nation state have made these contributions and non-members have not, and therefore members should have the right of access to welfare and non-members should not. It seems a straightforward and decisive ethical argument. However, there are two complications that make it very difficult to regard it as plausible. Firstly, we live in a globalised world economy. The idea of globalisation is a complex one, but all we need to note here is that the idea that citizens of a nation state are the only ones who contribute to the economic prosperity of that state is nonsense-many people throughout the globe make that contribution; economies are inextricably interconnected. Secondly, if we focus only on people who actually reside within the nation state, the fact is that many citizens make little or no economic contribution, whereas many migrants do. It is nonsense to assume that all migrants do not work or pay taxes and that all citizens do.

But even if we assume that we are only talking about illegal migrants who do not work or pay taxes, the argument still cannot avoid begging the question. We are now saying that "insiders" have contributed to the welfare system while "outsiders" have not, but the point remains that insiders are able to contribute to the national economy simply because they are on the inside, and they are on the inside through morally arbitrary factors. Outsiders have made no contribution to the economy simply because they happen to have been, up to now, legally outside the national border-but again, the fact that they are outsiders is determined by morally arbitrary factors. And so the distinction between those who have contributed to the welfare system and those who have not, to the extent that it is meant to act as the moral basis for the distinction between insiders and outsiders, rests on the morally arbitrary legal distinction between insiders and outsiders itself. Once more, the question has been begged in a fundamental sense.

The final option for the liberal theorist here is to bite the bullet and accept that national membership has no moral status, but argue that membership boundaries have an instrumental value. As Chris Brown ${ }^{8}$ puts it, this view argues that membership boundaries "are of instrumental value onlysimply administrative conveniences of no potential moral importance". Usually, it is argued that they promote liberty and welfare. The problem here, Brown points out, is that the liberty and welfare being promoted is that of members of the state-the liberty and welfare of non-members who are seeking access is being harmed. This solution, therefore, seems to bring us back to begging the question once more. It might be replied that liberal states have the right to expect other states to promote the liberty and welfare of their own citizens, and it is not the responsibility of a liberal state to step in where other states fail, and accept migrants seeking liberty and welfare of their own. But this amounts to saying that citizens of these other states are of no moral concern to us, and as this version of liberal theory retains the commitment to universalism, we cannot seriously make this response. Citizens of other states are of moral concern to us, and if we take liberal universalism seriously they are of equal moral concern. Of course, what we can do to assist citizens of other states is a highly complex problem given other factors, such as the international commitment to respecting nation state sovereignty; but once those citizens are within our national territory then, whatever their status, it is hard to see how we can morally justify excluding them from our systems of liberty and welfare. And, even if they are not within our territory, it is hard to see how we can morally justify putting obstacles in their way when they attempt to enter it.

\section{LIBERAL REALISM}

However, a final option is available to the liberal theorist beyond accepting complete freedom of access to the welfare system, and this is what I call liberal realism. I take "realism" here from international relations theory, as the view that as the international order is dangerously anarchic, the only rational approach for nation states is to pursue their self-interest. Realism rejects what it sees as "moralism" at the international level-the only rational course is to pursue a self-interested amoralism: the national interest is the only goal a state should pursue. ${ }^{9}$ This is to take a Hobbesian view of the international order, as a dangerous "natural condition" in which other states 
must be regarded as potential threats (Cole $\mathrm{P}^{7}$ chapter 8 ). Morality stops at the national border, and therefore ethical questions on global social justice are ruled out as irrational. This is not necessarily a complete amoralism, in that it could be argued that as realism is the most rational course to pursue in international affairs, it is therefore the most moral course to pursue-nation states have a moral obligation to pursue their national self-interest, which is after all the interest of their citizens. For a nation state to set aside its national interests, and therefore put the interests of its citizens in peril, would be profoundly immoral.

Liberal realism is the acceptance that liberal institutions such as a welfare system have to be protected by illiberal practices, and the justification of this by appeal to realist arguments to do with the national interest. A liberal democracy cannot sustain a welfare system or other liberal institutions without restricting membership and access. In addition, there is no ethically grounded distinction between citizens and migrants that the liberal state can appeal to in order to ethically justify this necessary discrimination. There may be other ways of restricting access that have nothing to do with this particular distinction, such as restricting healthcare to elderly people, or those who engage in practices that damage their health in expensive ways such as smoking tobacco, drinking alcohol, consuming drugs or engaging in "dangerous" sexual practices; but few of these would be as politically acceptable to the voting population as discriminating against migrants, or particular groups of migrants such as failed asylum seekers who are HIV positive. If we believe that the welfare system, and the NHS in particular, is a crucial institution for a just liberal order, then we must be prepared to take the necessary steps to protect it. Once we place that institution in the context of liberal universalism, global social justice and international human rights, we can see that to defend it by discriminating against migrants undermines the ethical basis of the institution itself and the whole philosophy that frames it. But in the context of liberal realism, we can say that it is our institution and we must have priority of access to it, while they must be excluded from it to some degree or other, and we have to avoid theorising the "we" and the "they". This is a brutally realist, self-interested decision, that we as a people are better off with a welfare state and the NHS, and that this "national" self-interest dictates that questions of international human rights and global social justice be set aside.

It may be objected that this is no solution to the problem at all, because what we were seeking was a moral argument for restricting migrant access to the welfare system, and this is a profoundly amoral one. I argued above that realism can be interpreted as a moral position, that the national interest ought to be prioritised. However, we cannot dig too deep here, because if we end up back at the position that the nation state ought to prioritise the interests of its own citizens over others, then we end up begging the question once more. If liberal realism is to be a moral solution to the problem-rather than a factual description of the attitude liberal theorists take to it which they dress up in the clothes of communitarianism - then it has to remain a morally brutal one with shallow foundations: that these institutions are valuable to us and therefore it is best for us that they are protected. This approach, of course, has enormous implications for the very idea of the welfare state and the very idea of international human rights and global justice. It may well be that the idea of international human rights and the question of global justice have no place within liberal political theory, because to place national liberal institutions within a global context undercuts their ethical foundations. All we are left with is the defence of our liberal institutions simply because they are our institutions-but not in the sense that they are liberal institutions and we are liberal individuals, such that we have a special relationship with them that can never be compromised. Rather, it is simply because they are the institutions that benefit us. Liberal realism is the only theoretically coherent and consistent position that can justify their protection, but its coherence and consistence can itself only be protected by keeping liberal realism a shallow and brutal philosophy. The exclusion of failed asylum seekers who are HIV positive, from free NHS treatment can only be understood within the context of this shallow brutality.

\section{ACKNOWLEDGEMENTS}

I thank Richard Ashcroft for suggesting that I write a paper on this particular topic, and his encouragement and advice throughout.

\section{Competing interests: None.}

A version of this paper was presented at the Imperial College Department of Primary Care and Social Medicine (DPCSM) Seminar Series in June 2005.

\section{REFERENCES}

1 United Nations. Human rights of migrants. United Nations document A/57/292. www.hri.ca/fortherecord2002/documentation/genassembly/a-57-292.htm (accessed 2 March 2007)

2 Ashcroft R. Standing up for the medical rights of asylum seekers. J Med Ethics 2005;31:125-6.

3 David Jacobson. Rights across borders: immigration and the decline of citizenship. Baltimore, MD: The Johns Hopkins University Press, 1997:38

4 Select Committee on Health. Third report. www.publications.parliament.uk/pa/ $\mathrm{cm} 200405 / \mathrm{cmselect} / \mathrm{cmhealth} / 252 / 25202 . \mathrm{htm}$ (accessed 2 Mar 2007).

5 Tamir Y. Liberal nationalism. Princeton, NJ: Princeton University Press, 1993.

6 Miller D. On nationality. Oxford: Clarendon Press, 1995.

7 Cole P. Philosophies of exclusion. Edinburgh: Edinburgh University Press, 2000

8 Brown C. Borders and identity in international relations theory. In Albert M, Jacobson D, Lapid Y, eds. Identities, borders, orders:rethinking international relations theory. Minneapolis, MN: University of Minnesota Press, 2001:120-1.

9 Brown C. Sovereignty, rights and justice: international political theory today. Cambridge: Polity Press, 2002:66-74. 